\title{
Public sphere
}

\section{Scientific expertise and policy-making: the intermediary role of the public sphere}

\author{
Arthur Edwards
}

The public sphere is a common place in which members of society meet to discuss matters of mutual interest. It is as tempting to scientists as a jar of honey is to bees. This is an important role for scientists. To be accountable for possible implications of research must not be the exception: it should be part of the standard repertoire according to which democratic control is maintained in the public sphere.
Arthur Edwards is in Department of Public Administration, Erasmus University Rotterdam, PO Box 1738, 3000 DR Rotterdam, The Netherlands; E-mail: edwards@bsk.fsw.eur.nl.
7 DHERE IS NO ADEQUATE MODEL available to picture the relationships between scientific expertise, public policy-making and the public.' With regard to the relationship between scientific expertise and policy-making, the decisionist model does not take into account that most problems for which policy-makers appeal to the sciences are contested normatively and that scientists do not refrain from taking stands on these issues. The technocratic model disregards the empirical uncertainty that results from competing theoretical perspectives and disciplinary approaches. Scientific claims are socially constructed and the state of affairs resulting from this is essentially pluralistic.

Apart from these shortcomings, both models treat the role of the public and of public debate in a way that falls short of the democratic self-understanding of late-modern societies. In the decisionist model, the role of the public is confined to the legitimation of policy decisions by periodic elections of the political leaders; in the technocratic model, even the choice between different teams of leaders and their respective platforms is stripped of any substantive importance. In short, both the decisionist and the technocratic model are empirically and normatively lacking.

Habermas's' pragmatic model provides a better starting-point, because it assumes an interaction between scientific experts and policy-makers, in which various points of view can be exchanged, as well as an important intermediary role of the public (Habermas, 1971):

a) the ideological basis of political power is seen as being accessible for critical arguments from science; 
Arthur R Edwards is Assistant Professor of Public Administration at the Erasmus University, Rotterdam. His research refers to the communication and information relationships between citizens and government and to the use of information communication technologies in these contexts. Among his recent publications is: Towards an informed citizenry?", in I Th M Snellen and W. B H J van de Donk (editors). Public Administration in an Information Age (IOS Press, Amsterdam, 1998).

b) the development of knowledge and technology is seen as being influenced by articulations of need resulting from political lines of argument;

c) the communication between scientific experts and policy-makers is guided by the 'social interests' and 'value orientations' of the lifeworld, and is, therefore, grounded on the communication between ordinary citizens. This communication between citizens is institutionalised in the form of public discussions taking place within the 'public sphere'. The public sphere encompasses all those forums or 'spaces' that are freely accessible for communication about public matters (see below).

We might say that the pragmatic model assumes a critical role of science in policy-making and leans towards a responsiveness-oriented role of politics in science. This process of reciprocal guidance of policy-making and science is rooted in the discourse of an active citizenry.

However, the pragmatic model is also unsatisfactory. To start with empirical objections, public communication and the interaction between experts and policy-makers are treated in a rather idealistic way, which does not take sufficient account either of the commercial mechanisms and other such factors steering the media, or of the strategic behaviour of policy-makers and scientists. From the knowledgeutilisation literature, it is well-known that both the appeal of policy-makers to science and their uses of scientific expertise are often tactically motivated and dependent on a variety of factors that bear on the 'political attention' an issue receives (Weiss, 1977). Among these factors are public opinion and the media. Moreover, the orientation of scientists to public opinion is itself not without strategic overtones.

With respect to considerations of normative democratic theory, the pragmatic model provides for an active role to be played by the public, but this role is

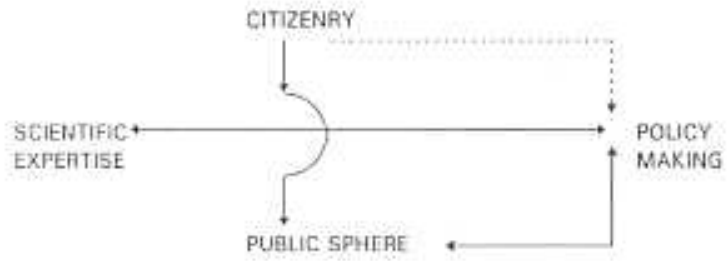

Figure 1. Intermediary role of public sphere according to decisionist model

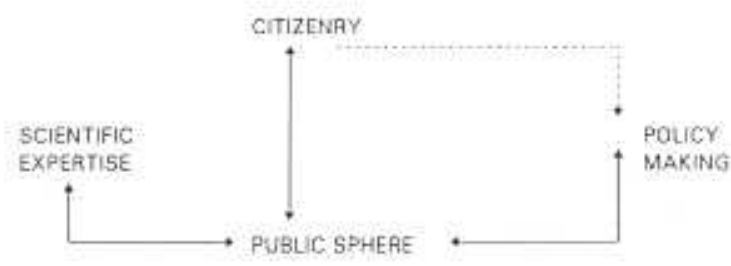

Figure 2. Public sphere as an intermediary structure between scientific expertise and policy-making

played out, as it were, in the background. The public does not participate directly in the interaction between scientists and policy-makers.

For empirical as well as normative reasons, any model of the relationships between scientific expertise and public policy-making has to take account of the intermediary role of public opinion, the media and other institutions that constitute the public sphere. Figure 1 gives a representation of these relationships according to the decisionist model, in which the public sphere fulfils the classical intermediary functions of (informal) democratic control and agenda-setting in the relationship between citizenry and politicians. It does not intervene in the relationship between seientific expertise and policy-making.

In Figure 2, the public sphere is depicted as an intermediary structure between scientific expertise and policy-making. In both figures, the dotted line stands for the formal democratic control on policymaking via the eleetoral process:

I surmise that the model in Figure 2 is gaining ground within the self-understanding of policymakers in public organisations. This would mean that they tend to abandon a decisionist conception of the relationship between scientific expertise and policymaking and look on scientific advice-giving more and more as a way to conduct public discussions.

If this is so, it might be a partial explanation of the apparent paradox that, although the sciences have lost their authority based on reliable knowledge and unanimous expertise, this has not led policy-makers to reduce their appeal to scientific advice-giving (Weingart, 1999). Decisionism has given way to 'political' or 'tactical', 'interactive' or 'dialogical' models of science utilisation. In all these models it is assumed that the potential impact of scientific insights on the opinion of relevant sections of the public is at least anticipated or also used instrumentally by policymakers.

Taking Figure 2 as a starting point, 1 want to propose in this article a theoretical perspective to examine these relationships. I suggest that this perspective should be dualistic. On the one hand, as the normative kernel of the concept of the public sphere, it should incorporate the notion of the ideal speech situation that underpins the pragmatic model (Habermas, 1971, page 75). On the other hand, it has to enable us to account for the strategic behaviour of scientists and policy-makers and the 'mediatisation' of public opinion. 


\section{In the public sphere people communicate about public matters: it occupies an autonomous position $v i s$-à-vis state and economy and in liberal democracies it provides democratic control, agenda-setting, co-ordination and societal learning}

Next, I will develop the concept of the public sphere. I distinguish between three institutional categories within the public sphere, viz: the media; social movements; and participatory forums or discursive arrangements between experts, citizens and policymakers. I suggest that these institutions can be examined fruitfully by the dualistic perspective in terms of 'system' and 'lifeworld', as proposed by Habermas.

Then I illustrate and expand my query by examining two divergent views on the role of the media in science-and technology-related public controversies. Finally, I show how the opposition of these views can be clarified by using Habermas's concepts. We focus on the three institutional categories of the public sphere.

\section{Public sphere}

The concept of the public sphere refers to a realm of social life in which people communicate about public matters and that occupies an autonomous position $v i s-\hat{a}-v i s$ the state and the economy. I follow Taylor's definition of the public sphere as the common spaces in which the members of society meet (through a variety of media or face-to-face encounters) to discuss matters of common interest (Taylor, 1995, page 295). In liberal democracies, the public sphere fulfils various important functions:

- democratic control: in addition to the formal control mechanism of periodic elections, it provides the citizens with an informal means of control on the exercise of (political) power;

- agenda-setting: it provides a channel for the articulation of problems felt in the sphere of private life and for their inclusion in the public and political agenda;

- co-ordination: it fulfils a co-ordinating function in the context of strategic interaction between politi$\mathrm{cal}$ and societal actors by providing information about their problem definitions, their views of permitted solutions and the like;

- societal learning: the permanent public discussions contribute to societal learning processes.

The decisionist conception of the relationship between science and policy-making incorporates the classical functions of democratic control and agendasetting. In Figure 1 we can project both functions without having to take into account the relationship between scientists and the public sphere. By including that relationship (Figure 2), we acknowledge that scientists are playing an important role in agendasetting, that they resort to media attention in furthering their normative stands on issues as well as their strategic aims, and that scientific advice-giving has an educational potential for society, if mediated by public discussion.

The functions of the public sphere are fultilled by various institutions, of which I distinguish three categories. In addition to the media, I include social movements and discursive arrangements. Social movements adopt 'dual politics', in the sense that they pursue their own substantive political goals (and seek to gain public attention for them via the media), and at the same time create autonomous public spaces for communication (Habermas, 1992a, page 447).

Discursive arrangements are set up specifically for public deliberation. Their inclusion as an institutional category within the public sphere is only warranted in so far as they are open to the participation of citizens and when there is institutional room for them to codetermine the agenda.

The functioning of these institutions can be exam. ined in terms of two basic concepts within Habermas's theory of communicative action, namely 'system' and 'lifeworld'. In the first instance, these two concepts can be seen as referring to societal domains governed by different mechanisms of integration. The lifeworld encompasses those realms of society that are reproduced by social rules governing face-to-face communication, traditions, cultural norms, solidarity and so on.

The system refers to those realms of society that are ruled by 'steering media', which means that coordination between actions takes place by means of money and power, independent of the intentions of actors (Habermas, 1981). In this approach, the public sphere can be seen as the public component of the lifeworld. Figure 3 places the public sphere within this framework.

This representation has some theoretical value, in so far as it gives an ideal-typical characterisation of the public sphere, as a domain in which interaction is

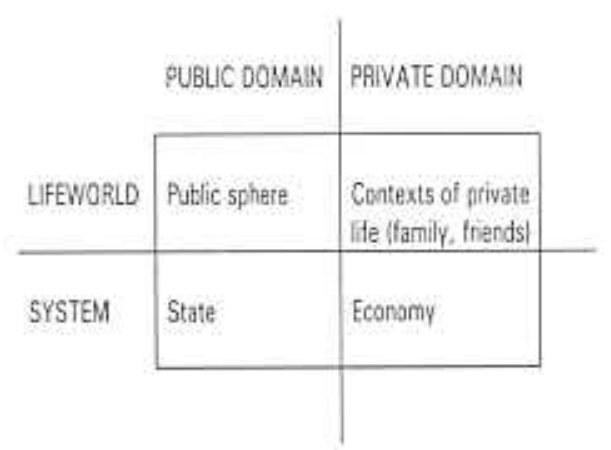

Figure 3. Framework for positioning public sphere

Source: Adapted from Peters (1993) 
governed by argumentation rules and not by monetary and power mechanisms. I will use 'system' (or 'subsystems') and tifeworld' as provisional terms to denote societal domains.

However, this model is somewhat misleading as an instrument for empirical research. The discussion about these Habermasian concepts suggests that the lifeworld/system distinction can be used more fruitfully as an analytical tool than as a conceptualisation of concrete institutional domains such as the burcaucracy, the sciences and the mass media. ${ }^{2}$ As analytical tools, these concepts stand for different mechanisms for social integration. In principle, every domain of interaction can be looked at in both ways.

For example, by using both a lifeworld perspective and a systems perspective, the mass media can be studied as ambiguous institutions that have, as Habermas (1962, page 233) puts it, "the Janusface of enlightenment and control; of information and advertising; of pedagogy and manipulation" [translated]. Using a lifeworld perspective, we try to observe the nomative ideas and social rules that are shared by actors in their daily praxis. Using a systems perspective, we look at the chains of unintended effects by which social systems are reproduced.

I will use Luhmann's (1988) concept of 'resonance' to denote the way in which situations and changes in the environment can bring about reactions within systems. Luhmann emphasises that systems can only react to events in the environment in a way that is consonant with their own logic or frame of reference.

\section{Role of the media in public controversies}

In the literature, different viewpoints are taken as to the 'rational' character of conduct in public controversies, particularly on the role of the media. On one hand, one can adopt the normative conception of the public sphere as a realm of rational discourse. In his account of the role of the mass media in controversies about acid rain and whaling regulation in Norway, Roll-Hansen (1994) shows how the media contributed to a biased public opinion on these issues and how this bias affected political decision-making. According to Roll-Hansen, "a common interest in truth is an underlying premise in the standard treatments of the relationship between science and the mass media". However, he concludes that the commercial competitive regime of modern mass media seems to be in conflict with the conditions for a rational debate.

In a discussion of science- and technology-related public controversies, Rip (1987) follows another tack. He presents a rhetorical perspective in which interests and strategic action play an integral role alongside rational argument. In this perspective "not truth, but impact is what counts" (page 325). Public controversies are vital for societal learning processes, but, to stimulate these, simple notions about 'consensus' and 'dominance-free debates' have to be abandoned, and, instead, there is a need to "work with, and through the strategizing of actors" (page 262). Within this approach, the role of the media can also be seen in a somewhat different light (page 364):

"Media reporting of controversial issues may act as a flywheel ... But it has also a mediating function, in the sense that it creates an arena and introduces requirements of (some) credibility".

Empirically, these two authors make the same observations. However, Roll-Hansen refers to a normative idea of the task of the media, namely "enlightenment". The contrast between empirical observations and normative ideal seems to lead to an impasse. This has to be taken all the more seriously when we consider that 'enlightenment' is not only an underlying premise in what Roll-Hansen calls the "standard treatment" of the task of the media and the sciences, but an integral element of the western democratic tradition.

Rip's rhetorical approach seems to be able to cope better with the reality of strategic interaction. Also, he suggests that at least some functions of the public sphere that refer to normative democratic theory (as societal learning) can be fulfilled by mass media that are oriented towards 'impact' instead of 'truth'. However, he may underestimate the degree to which a normative argumentative conception of the public sphere, which he denounces, has empirical reference. For example, a challenge for empirical research as well as for institutional design would be to discover the 'room' for discursive arrangements between policy-makers, scientific experts and citizens as democratic intermediary institutions. I take up this question later.

\section{Dualistic approach to the media}

Previously, I referred to Peters' (1993) characterisation of the media as "ambiguous institutions". In a lifeworld perspective, the media appear as an intermediary that condenses the more or less spontaneous communications taking place in the networks of daily life: in this way the media contribute to the shaping of 'communicative power' of citizens vis-àvis the political system. According to Habermas, this

\section{In a lifeworld perspective, the media appear as an intermediary condensing the spontaneous communications taking place in the networks of daily life: in a systems perspective, the media appear to be steered by commercial mechanisms}


agenda-setting function of the public sphere becomes particularly manifest in circumstances in which a crisis situation is perceived in the lifeworld (Habermas, 1992a). In these cases, public initiatives external to the political system and the government often succeed in taking the initiative, successfully appealing to the available critical self-understanding of journalists, and reaching the political agenda.

In a systems perspective, the media appear to be steered by commercial mechanisms. Societal actors try to make use of 'media power' to enlarge their economic or political market share. The agendasetting function of the media can be effective when communicative power gains resonance in the political system, thanks to the anticipation of political actors concerning possible gains or losses in their electoral market share. For politicians, the media fulfil an essential co-ordination function.

There are two directions for empirical research along these lines. In the first place, from a lifeworld perspective, the nomative conceptions and social rules that underlie the self-understanding and daily work of journalists have to be examined. The prominent 'theory of the social responsibility of the press', as it was formulated by the American Commission on Freedom of the Press (1947) can be seen as a practical translation of the normative conception of the public sphere in that period:

"1 a truthful, comprehensive, and intelligent account of the day's events in a context which gives them meaning;

2 a forum for the exchange of comment and criticism;

3 a representative picture of the constituent groups in society

4 the presentation and clarification of the goals and values of the society;

5 full access to the day's intelligence."

One research question is whether and how these ideas are effective in practice. In so far as these ideas are in fact effective, such a self-understanding can function as a counter-steering mechanism within the commercial environment of the journalists 'practice. Research by Snijders (1994) has established that Dutch newspaper editors employ certain rules of conduct that are also the subject of reflection and discussion.

As a commercially operating system, the media function according to specific selection rules regarding the 'news value' of events. The selection rules of the media are, of course, bias-producing. They contribute to a state of affairs in which surprising events, disasters, threats and the like have much news value, and complex and ambiguous matters are simplified, wrongly understood or ignored (Ruhrmann, 1994). Therefore, another research question is how these attention rules interact with the rules of the social responsibility of the press.

A second research theme is the resonance that media attention can bring about on the political system (and other societal subsystems), for example by creating a more problem-conscious environment. The accounts of Roll-Hansen (1994) and Roqueplo (1995) on the acid rain issue in Norway and Germany are illustrations of how the media in their orientation on news value can act as powerful multipliers of public concern, "which forced the government to make a number of rapid decisions" (Roqueplo, 1995).

\section{Social movements}

The public sphere overlaps with the civil society, the realm of associations, public initiatives by citizens and social movements. Habermas envisages a model of the protection of the lifeworld by new social movements exercising indirect influence on the system (Habermas, 1985, page 423). According to this model, the actions of social movements work as stimuli for the socictal subsystems to enhance their capability for self-reflection, or, in other words, their sensitivity to reactions of the social environment. This would be conceptualised by Luhmann as "resonance"!

The optimal strategy for the new social movements would consist of engaging in 'border conflicts', without actually crossing the borders of the subsystems. Habermas speaks of "innovative combinations of power and intelligent self-limitation". Without a programme of self-limitation, the goals of the social movements would lose touch with the orientations of their members and become dependent on imperatives of organisational self-maintenance within a mediasteered environment.

How do social movements behave in these 'border conflicts' and what can be said about their impact?

In their research de Bruyn et al (1995) concluded that social movements have a strained relationship with democracy. At times, they break the most elementary rules of rational debate, but, eventually, this can contribute to the overall quality of public discussion by opening up the agenda for new issues and problem definitions. The movements were quite successful in terms of public agenda setting, but much less so in terms of influence on actual decisionmaking.

When using a lifeworld perspective, we can observe that social movements act both communicatively and strategically in order to mobilise the public. to articulate problems and issues and to influence the public and political agenda. When using a systems perspective, we can observe that social movements sometimes cross the boundaries of the systems they encounter and adapt their behaviour to the logic of the interorganisational play of power.

For example, in his research on discourse coalitions in the British acid-rain controversy, Hajer (1993) established that the ecomodernist coalition (in which environmentalist associations participated), instead of persisting to put the acid-rain issuc into the context of the structural problems of modem 
industrial society, resorted to a reformist argumentative strategy. They tried "to beat the traditional pragmatists at their own game by employing utilitarian and scientific arguments" (Hajer, 1993, page 68). Hajer observed that, whereas the ecomodernists adapted to reformist argumentation, the traditional pragmatists adopted many ecomodernist concepts, without changing their policy practices of course.

The net effect of this game was that the controversy was resolved by a technical 'end-of-pipe' solution. The ecomodernists failed to impose their frame on the acid-rain debate or transform existing policy practice. However, Hajer suggests that the ecomodernist concepts that were accepted by the British government might prove to be Trojan horses. He points to pressures from the international political environment (treaties on the environment, the European Union) in which these concepts gained a certain foothold.

\section{Discursive arrangements}

Several authors have taken up the idea of a discursive or deliberative democracy, a political order in which the citizens "share a commitment to the resolution of problems of collective choice through public reasoning, and regard their basic institutions as legitimate in so far as they establish the framework for free public deliberation" (Cohen, 1989, page 21). Dryzek envisages "discursive designs" that are located in, and help constitute, as he puts it, "a public space within which citizens associate and confront the state" (Dryzek, 1990). As examples of incipient discursive designs he mentions environmental mediation and regulatory negotiation involving face-to-face negotiation among the parties interested in a regulation.

Among others, Fischer (1993) has argued for a participatory policy analysis, in which co-operative relationships between scientists and citizens can develop, and the role of experts is reconceptualised as facilitating public learning and empowerment. Bechmann (1993) distinguishes the participative model of technology assessment (TA) besides the instrumental and the élitist models. According to Bechmann, TA has not only the function to organise knowledge on the possible impacts of technological innovations, but also to stimulate and make more rational society's discourse on technological development.

As I see it, both Fischer and Bechmann firmly base participative policy analysis and TA on the normative model of the public sphere. In addition, Bechmann sees participative TA as a step towards a "more forceful integration" of the public into decision-making in technology policy (Bechmann, 1993, page 15). He formulates some guiding principles on how to conduct participative TA, one of which holds that "the public has authority to make decisions or codetermine politics in collaboration with government officials" (page 15).

Bechmann thematises here the question of how participative TA is to be located between the lifeworld

\section{A legal framework should be created which institutionalises technology assessment as autonomous arrangements for discussion between citizens, scientists and policy-makers, and governs its relationship with the political system}

(the discourse of the public) and the political system (decision-making). Hennen takes up this discussion in his article on TA discourses (Hennen, 1995). He endorses the point of view that TA discourses must intermediate (my italics) between open public discourse on technology and political decision-making:

"However, TA is only able to perform its function as 'intermediary system' to the extent that it is neither a replacement for public controversies nor a substitute for parliamentary decision making" (page 108).

In this way, a fundamental design question is formulated that reminds us of Habermas' formula about social movements of "the innovative combination of power and intelligent self-limitation". According to the normative conception of the public sphere, TA processes should be structured in such a way that they remain open to all kinds of demands and points of view articulated in societal debates. This would imply that TA processes remain relatively independent of decision-making in the political and administrative subsystems.

However, the same intermediary function implies that TA processes contribute to a certain selection and integration of these demands and points of view, and that they exert a certain influence on political decisions. In this context, I think it is important to differ" entiate between participation in decision-making and exerting influence on it. The combination of an open public discourse and decision-making in one arrangement may overburden it and blur political responsibilities. As Habermas puts it: "Discourses do not govern. They generate a communicative power that cannot take the place of administration but can only influence it" (Habermas, 1992a, page 447).

Therefore, I follow Hennen's suggestion that a legal framework should be created which institutionalises TA as autonomous arrangements for discussion between citizens, scientists and policy-makers, and governs its relationship with the political system. 1 add to this that 'discussion' can include the coproduction of proposals for political decision-making. In this way, the management of boundaries between scientific expertise, public sphere and policy-making - "boundary work" as it is discussed by Jasanoff (1990) - can be given an institutional form. 
Still, we have to address the question of how (formal) TA processes, their design and institutionalisation relate to the reality of strategic co-ordination in those fields in which many of the actors who are expected to participate in TA discourse, operate. The economy and public administration as well as the fields of expertise are, at least partially, steered by monetary and power mechanisms.

At this point, Rip's observation should be noted "that it is not realistic to expect the parties in a controversial issue to stop their strategizing, sit down together for a herrschaftsfreie Diskussion ...., and reinsert the results into the struggle so that it will be resolved" (Rip, 1987, page 362). Both the stimulus for actors to participate and the impact of TA processes are dependent on certain conditions that have to be created in their design and institutionalisation.

Sclove (1994) has indicated that the Danish consensus conferences have created a more critical environment for Danish corporations. The corporations seem to have benefited from this because the participatory approach enabled them to anticipate better any possible negative reactions from the public and so to improve their products at an early phase. Here we see again the co-ordination function of the public sphere at work.

This observation suggests that the impact of TA processes is not only dependent on formal provistons regarding the use of their results in decision-making. Taking a systems perspective, we see that TA processes can have a resonance of their own in the operations of the subsystems. This impact of TA processes will be dependent to a great extent on credibility factors, as perceived by those actors that 'represent' the societal subsystems (Fixdal, 1997).

\section{Conclusion}

Any model of the relationship between scientific expertise and public policy-making should include the public sphere, that is, those common spaces in which citizens meet to discuss public matters. By including the intermediary role of the public sphere in this relationship, we acknowledge that scientists participate in public agenda-setting and make use of media attention in furthering their normative stands on issues as well as their own strategic aims.

We can also account for the public learning potential of scientific advice-giving, if mediated by public discussion. Furthermore, we assume that the potential impact of scientific insights on the opinion of the relevant public is anticipated or used instrumentally by policy-makers. In normative terms, the concept of the public sphere refers to democratic values, namely public accountability and active citizenship.

1 surmise that this conception of the public sphere is also gaining ground in the practice of public policy-making. This might be a partial explanation of the apparent paradox that, although the sciences have lost their authority based on reliable knowledge and unanimous expertise, this has not lead policy-makers to reduce their appeal to scientific advice-giving.

The public sphere fulfils four important functions in society: democratic control; agenda-setting; coordination; and societal learning. I distinguish three institutional categories within the public sphere: the media; social movements; and discursive arrangements between experts, citizens and policy-makers. By using Habermas' dualistic theory of lifeworld and system, I have tried to show how the functions of the public sphere can be fulfilled by these institutions.

On the one hand, these functions may be fulfilled, more or less directly, by the rule-following action of journalists, social movements and participants in participative TA or policy analysis. On the other hand, this action may bring about indirect and unintentional effects ('resonance') in the political system or other societal subsystems. With regard to action strategies and institutional design, Habermas's theory underlines the importance of a careful management of boundaries between the spheres of scientific expertise, public discussion and decision-making on policies.

\section{Notes}

1. 'Policy-making' is here understood to mean the process of formulating a plan for courses of action by a government. 'Policy-makers' are the professionals who work within governmental agencies and are involved in policy-making. 'Scientific expertise' is in this context the scientific advice-giving by knowledge institutions outside governmental agencies.

2. See, for example, McCarthy (1991, pages 152-180). This is also acknowledged by Peters (1993).

\section{References}

G Bechmann (1993), "Democratic function of technology assessment in technology policy decision-making". Science and Public Policy, 20 (1), February, pages 11-16.

$\checkmark$ Cohen (1989), "Deliberation and democratic legitimacy" in A Hamlin and $P$ Pettit (editors). The Good Polity, Normative Analysis of the State (Blackwell, Oxford) pages 7-34.

Commission on the Freedom of the Press (1947). A Free and Responsible Press (University of Chicago Press, Chicago).

$J$ de Bruyn, L W J C Huberts and D Oegema (1995), "Sociale bewegingen, publiek debat en democratie", in K van Kersbergen and I M A M Pröpper (editors). Publiek debat en democratio (SDU Uitgeverij, Den Haag).

I S Dryzek (1990). Discursive Democracy: Politics, Policy and Political Science (Cambridge University Press, Cambridge).

F Fischer (1993). "Citizen participation and the democratization of policy expertise: from theoretical inquiry to practical cases". Policy Sciences, 26, pages 165-187.

$\checkmark$ Fixdal (1997), "Consensus conferences as extended peer groups'", Science and Public Policy, 24(6), December, pages $366-376$.

$J$ Habermas (1962). Strukturwandel der Offentlichkeit (Luchterhand, Neuwied).

$J$ Habermas (1971). Toward a Rational Sociefy (Heineman. London).

J Habermas (1981). Theorie des Kommunikativen Handeins (Suhrkamp Verlag, Frankfurt am Main).

J Habermas (1985), Der Philosophische Diskurs der Moderne (Suhrkamp Verlag. Frankfurt am Main).

I Habermas (1992a), Faktizital und Goltung (Suhrkamp Verlag. Frankfurt am Main).

J Habermas (1992b), "Further reflections on the public sphere", in C Calhoun (editor), Habermas and the Public Sphere (MIT Press, Cambridge MA). 
M A Hajer (1993), Discourse coalitions and the institutionalization of practice: the case of acid rain in Britain", in F Fischer and $J$ Forester (editors), The Argumentative Tum in Policy Analysis and Planning (Duke University Press/ UCL Press, Durham/London) pages 43-76.

L Hennen (1995), "Discourses on technology: public debates in technology and technology assessment as symptoms of reflexive modernization", in R von Schomberg (editor), Contested Technology: Ethics, Risk and Public Debate (Intemational Centre for Human and Public Affairs, Tilburg/Buenos Aires) pages $91-117$.

S Jasanoff (1990). The Fitth Branch; Science Advisers as Policy. makers (Harvard University Press, Cambridge MA)

NLuhmann (1988), Cokologische Kommunikation (Westdeutscher Verlag, Opladen).

T McCarthy (1991), Ideals and I/usions (MIT Press, Cambridge MA).

J D Peters (1993), "Distrust of representation: Habermas on the public sphere", Media, Cuifure and Society, 15, pages 541-571.

A Rip (1987). "Controversies as informal technology assessment", Knowlodge, Creation, Diffusion, Utilization, 8(2), pages 349-371.
L Roll-Hansen (1994). "Science, politics and the mass media: on biased communication of environmental issues", Science, Technology and Human Values, $19(3)$, pages 324-341.

P Roqueplo (1995), "Scientific expertise among political powers. administrations and public opinion", Science and Public Policy, 22(3). June, pages 175-182.

G Ruhrmann (1994), "Offentliche Meinung", in K Dammann, D Grunow and KP Japp (editors), Dio Verwaltung des Politischen Systems (Westdeutscher Verlag, Opladen).

R E Sclove (1994)، "Citizen-based technology assessment? An update on consensus conferences is Europe", http://www,manymedia.com/lokalloka.1.12.txt.

M L Snijders (1994). "De schuchtere relatie fussen Nederlandse media en de ethiek", in M L Snijders and J van Dijk (editors), Ethiek in de joumalistiok (Cramwinkel, Amsterdam).

C Taylor (1995), Philosophical Arguments (Harvard University Press, Harvard).

P Weingart (1999), "Scientific expertise and political accountability: paradoxes of science in politics", Science and Public Poficy. 27(3), June, pages 151-161.

C Weiss (1977), Using Social Research in Public Policy Making (Lexington Books, Lexington). 